\title{
DRAGUTIN DOMJANIĆ I ZLATA KOLARIĆ-KIŠUR - ZAVIČAJNI PISCI U NASTAVI HRVATSKOGA JEZIKA U OSNOVNOJ ŠKOLI
}

\section{Sažetak}

Učenici u školu dolaze sa znanjem svoga zavičajnoga idioma, a potom se u školi susreću sa standardnim jezikom i njegovim normama. No, unatoč težnji za ovladavanjem standardnim jezikom, u nastavi hrvatskoga jezika izuzetno je važno očuvati zavičajni idiom. Načelo zavičajnosti prisutno je u metodikama nastave hrvatskoga jezika, a ističe kako učenicima treba na njima bliskim sadržajima približiti usvajanje nastavnoga gradiva i kako treba njegovati raznolikost narječja jer su ona bogatstvo hrvatskoga jezika (Težak, 1997.). I hrvatska narječja i jezični standard zaslužuju svoje mjesto u učenju hrvatskoga jezika te se učenike treba poticati na njihovu primjerenu i ispravnu jezičnu uporabu.

U četvrtome razredu osnovne škole učenici na nastavi Prirode i društva obrađuju Republiku Hrvatsku (NPiP, 2006.). Povezujući nastavne sadržaje, ovaj će rad učenicima približiti dva zavičaja: Hrvatsko prigorje (područje oko Svetoga Ivana Zeline) i Slavoniju (požeško područje) kroz djela dvaju pisaca: Zlate Kolarić-Kišur i Dragutina Domjanića. Zlata Kolarić-Kišur svojim je autobiografskim pričama i uspomenama iz djetinjstva, u knjizi Moja Zlatna dolina, odličan zavičajni predložak za upoznavanje požeškoga kraja u njegovoj cjelovitosti (međuljudskih odnosa, zgoda i nezgoda u vrijeme odrastanja), za upoznavanje jezičnoga bogatstva požeškoga govora te zavičajnih običaja.

Izbor iz pjesama Dragutina Domjanića, u kojima učenici prepoznaju obilježja prigorskoga zelinskoga kraja, običaje koji taj kraj čine posebnim i koji su vrijedno kulturno bogatstvo, baš kao i kajkavsko narječje kojim su te pjesme pisane, drugi su književni predložak na kojemu će učenici u nastavi hrvatskoga jezika učiti o ljepoti svoga zavičaja.

Radom će se istražiti koliko su književni predlošci dobra podloga za učenje o užem i širem zavičaju te koliko učenici rado u nastavi prihvaćaju bliske im sadržaje iz neposredne životne okoline: poznate krajeve i jezik. Nakraju će se provjeriti i koliko su učenici, potaknuti zavičajnicima, spremni i sami napisati književni tekst o svome zavičaju na zavičajnome idiomu ili na hrvatskome standardnome jeziku.

Ključne riječi: kajkavsko narječje; štokavsko narječje; zavičajna književnost; načelo zavičajnosti; učenje hrvatskoga jezika. 


\section{Uvod}

U ovom radu proučavat će se dvoje pisaca: Zlata Kolarić-Kišur i Dragutin Domjanić. S ciljem da se kroz nastavu Hrvatskoga jezika povežu dva kraja Republike Hrvatske i da se učenike potakne na čitanje književnih djela te na stvaranje književnih tekstova, prezentirat će im se zbirka pripovijedaka Moja Zlatna dolina Zlate Kolarić-Kišur i pjesme Dragutina Domjanića. To dvoje književnika ne povezuje se u hrvatskoj književnosti, ali su za potrebe ovoga rada poslužili kao dva književna uzora učenicima četvrtih razreda OŠ Dragutina Domjanića u Svetome Ivanu Zelini. Oboje se nazivaju zavičajnim piscima jer i jedno i drugo u svojim djelima nadahnuće pronalaze $u$ svome zavičaju te su sve pripovijetke i pjesme prepoznatljive i danas ljudima koji žive u Požegi ili prigorskome (posebno zelinskome) kraju. Oboje pisaca u svojim se djelima služe narječjima svoga kraja: štokavskim narječjem Zlatne doline i kajkavskim narječjem zelinskoga Prigorja. Kako su hrvatska narječja u nepovoljnijem položaju od hrvatskoga standarda (Hranjec, 2009., 421-524) i kako djeca vrlo često imaju osjećaj da ,je pogrešno u školi govoriti kao što govore doma“, jedan od ciljeva ovoga rada bio je potaknuti djecu na kajkavski izraz: u školi i kod kuće.

Današnja su djeca djeca suvremenih medija. Pisana je riječ potisnuta, a svoj zamah dobili su informatički sadržaji koji malo toga ostavljaju mašti, a narušavaju koncentraciju. Zbog velike količine informacija koje u vrlo kratkom vremenu bivaju proslijeđene primatelju, otežano je usvajanje informacija i njihovo trajnije pamćenje. Čitanje knjiga za većinu je učenika samo obaveza koju dobiju s popisom lektire, ali ne uživaju u njoj. Malo učenika čita u slobodno vrijeme. A čitanje, za razliku od računala, interneta i suvremene informatičke tehnologije (koja ima svoje zasluge, ali ne i isključivu prednost pred svim ostalim aktivnostima), potiče maštu, kreativno razmišljanje, čitatelj proširuje svoj rječnik te povećava vlastitu sposobnost izricanja stavova, misli i osjećaja. Stoga je jedan od ciljeva ovoga rada i potaknuti učenike na čitanje - u ovom slučaju djela Zlate Kolarić-Kišur i Dragutina Domjanića.

Hrvatski jezik kao nastavni predmet mora poticati razvoj komunikacijske kompetencije osnovnoškolske djece. U Nastavnom planu i programu za osnovnu školu kao cilj nastave Hrvatskoga jezika navodi se da je to "ovladavanje standardnim jezikom, a (ono) pridonosi (između ostaloga) razvoju literarnih sposobnosti, čitateljskih interesa $i$ kulture; (...) razvijanju poštovanja prema jeziku hrvatskoga naroda, njegovoj književnosti $i$ kulturi“. (NPP, 2006., 25) Cilj će se ostvariti kroz zadaće koje su definirane za svako od četiriju nastavnih područja koja čine Hrvatski jezik u osnovnoj školi (hrvatski jezik, književnost, jezično izražavanje i medijska kultura). Kao zadaće navode se, između ostaloga, „suzbijanje straha od jezika; osvješćivanje razlika između standardnoga jezika i zavičajnih idioma; postupno usvajanje hrvatskoga jezičnoga standarda; (...) razvijanje osjetljivosti za književnu riječ; razvijanje čitateljskih potreba; stvaranje 
čitateljskih navika; osposobljavanje za samostalno čitanje i primanje (recepciju) književnih djela“, a sve kako bi se ostvario temeljni cilj nastave Hrvatskoga jezika „osposobiti učenike za uspješnu jezičnu komunikaciju koja im omogućuje ovladavanje sadržajima svih nastavnih predmeta i uključivanje u cjeloživotno učenje“. (NPP, 2006., 25) Riječ, pisana i govorena, temelj je nastave Hrvatskoga jezika. Učenici čitanjem ulaze u komunikaciju s književnim tekstom koji potiče njihovo sudjelovanje $\mathrm{u}$ njegovoj percepciji te „razvija sposobnost izražavanja doživljaja, osjećaja, stavova i misli“ (NPP, 2006., 25) u svim životnim područjima.

„Stvaranje uvjeta za razvoj komunikacijskih sposobnosti i povećanje komunikacijske kompetencije (osposobljenosti) na razini svih priopćajnih idioma materinskoga jezika trebao bi biti važan cilj uspješnoga institucionalnoga učenja i poučavanja hrvatskoga jezika u ranoj fazi jezičnoga usvajanja. Istraživanja potvrđuju da je razvijenija komunikacijska sposobnost proporcionalna uspješnijoj socijalizaciji, a utječe i na cjelokupan razvoj svestrane stvaralačke ličnosti." (Pavličević-Franić, 2005., 81)

Da bi se uspješno ostvarili ciljevi nastave Hrvatskoga jezika, potrebno je djecu osloboditi straha od upotrebe hrvatskoga jezika u različitim govornim situacijama, osvijestiti im da je svako hrvatsko narječje dio hrvatskoga jezičnoga blaga te da zajedno s hrvatskim standardnim jezikom čini cjelovit sustav hrvatskoga jezika. Sve dok je učenicima teško izraziti se standardnim književnim jezikom, potrebno je stvoriti uvjete za primjenu zavičajnoga idioma preko kojega će postupno usvojiti jezični standard. Ne dozvoliti učenicima da se slobodno izražavaju znači potisnuti u njima sav njihov stvaralački i jezični potencijal te spriječiti njihov cjelovit razvoj. Nastava Hrvatskoga jezika mora o tome voditi računa.

\section{Stvaralaštvo Zlate Kolarić-Kišur}

Zlata Kolarić-Kišur rođena je u Slavonskome Brodu 29. listopada 1894. Djetinjstvo je provela u Požegi, a kasnije je živjela u Zagrebu, gdje i umire 24. rujna 1990. U Požegi je provela sretno djetinjstvo te je Požega postala njezino stalno nadahnuće za književno stvaralaštvo. Svoju prvu zbirku pjesama, Naš veseli svijet, objavljuje 1933. godine, a pjesme je počela pisati za svoju kćer. Uz navedenu zbirku, objavila je i zbirke Smijte se djeco! (1935.), Po sunčanim stazama (1951.) i Uz pjesmu i šalu na jadranskom žalu (1961.). Pjesme su joj radosne, pune životnoga optimizma i sretnoga djetinjstva. Tematski su vezane uz bliske ljude i kraj, opisuju djetinjstvo, životinjski i biljni svijet te doživljaje iz autoričina djetinjstva. Namijenjene su djeci i mladima. I opsežno prozno i dramsko stvaralaštvo Zlate Kolarić-Kišur namijenjeno je, prije svega, mladoj čitateljskoj publici te ona svojim djelima nastoji prenijeti životnu vedrinu, poučiti čitatelja, potaknuti maštu i pružiti neponovljiv čitateljski doživljaj. 
Napisala je igrokaze Nadina velika tajna (1934.), Kristalni zvončići (1953.), Hrabri miš i pustolovni vitezovi (1954.), komediju Ljetovanje tetke Anastazije (1938.), proturatnu društvenu dramu Povratak (1940.) te djela namijenjena mlađim čitateljima Dječje igre (1953.), Cvijeće (1955.), Ptičji festival (1958.), Teta Beta (1958.), Zamršeni slučaj (1961.), Potrkalo postaje asistent (1961.), Golema sreća u malom svijetu (1962.), Jedan mali život (1966.), Dick Whittington i njegov mačak (1968.), Moja Zlatna dolina (1972.), Moje radosti (1981.).

Najpoznatija je autobiografska zbirka pripovijedaka Moja Zlatna dolina u kojoj na duhovit, pristupačan, maštovit i slikovit način autorica mladom čitatelju približava ljude i mjesta svoga djetinjstva i čini čitatelja dijelom svoje obitelji. S čitateljem proživljava duhovite zgode svoga djetinjstva, a svojim opuštenim stilom pripovijedanja, mladome čitatelju potiče maštu, budi radoznalost i potrebu da čita dalje kako bi sudjelovao u novoj zgodi iz autoričina života. Jednako kao što ga poučava empatiji i potiče da suosjeća s njom kada se na kraju zadnje pripovijetke autorica oprašta sa svojom Zlatnom dolinom i odlazi, kako sama kaže, iz Zlatne doline u moj novi, budući život... (Kolarić-Kišur, 1986.)

\section{Stvaralaštvo Dragutina Domjanića}

Dragutin Domjanić pisac je Hrvatskoga prigorja. Rođen je 12. rujna 1875. u Krčima, kraj Svetoga Ivana Zeline. Umire u Zagrebu 7. lipnja 1933. Kao pripadnik stare plemićke obitelji, živio je u vlastelinskim dvorcima svoje obitelji u Krčima i u Donjoj Zelini. Školovao se u Zagrebu, gdje je završio osnovnu i srednju školu kao pitomac Plemićkoga konvikta, a kasnije i Pravni fakultet. Doktorirao je na Pravnome fakultetu te je radio kao sudac istražitelj, vijećnik pri Banskom stolu i civilni sudac na Kotarskome sudu. Od 1919. član je JAZU, bio je predsjednik Matice hrvatske i predsjednik jugoslavenskoga PEN-kluba.

Godine 1907. objavio je štokavsku zbirku pjesama Pjesme (1907.). Nakon nje piše pjesme na kajkavskome narječju u kojima, zajedno sa svojim suvremenicima, Antunom Gustavom Matošem i Franom Galovićem, vraća značaj kajkavskom jeziku i kajkavskome književnome izrazu te je, prema riječima Miroslava Šicela, jedan od proih pjesnika (uz Galovića) koji je dokazao izražajne mogućnosti kajkavske riječi (prema Skok, 1983.).

Poznato je da je Dragutin Domjanić bio životno pasivan, povučen i da se kretao u vrlo uskom društvenome krugu. Njegove su pjesme bile svojevrstan bijeg iz činovničke i društvene svakodnevice i životnoga sivila. Pjesme Dragutina Domjanića odlikuju se slikovitošću i melodioznošću. Prikaz su životnih trenutaka, ljudi i krajolika. U njima pjesnik živi jednu drugu, ljepšu životnu stvarnost. Najpoznatije su mu 
zbirke pjesama Kipci i popevke (1917.), V suncu i senci (1927.) i Po dragomu kraju (1933.). Neke su od Domjanićevih pjesama i uglazbljene: Fala, Kaj i Poperke sem slagal.

Dragutin Domjanić nije dječji pisac, ali je zbog svojih zavičajnih motiva i jezičnoga izraza vrlo blizak djeci prigorskoga kraja jer u njegovim izrazima prepoznaju svoj domaći izričaj, a u motivima svoj vlastiti kraj. Stoga je kao zavičajni pisac dobar književni uzor i poticaj učenicima da i sami stvaraju na kajkavskome narječju.

\section{Zlata Kolarić-Kišur i Dragutin Domjanić kao poticaj za samostalno literarno stvaralaštvo učenika}

Zlata Kolarić-Kišur zavičajni je pisac štokavskoga jezičnoga izraza i prisutna je u lektiri za osnovnu školu. Prema Nastavnom planu i programu za osnovnu školu (2006.), može se, ali i ne mora, čitati u 4. razredu. Prema provedenom istraživanju, utvrđeno je da se Moja Zlatna dolina nalazi na popisu lektire četvrtih razreda isključivo na području Slavonije (Aladrović Slovaček, Marić, 2013.) i da učenici OŠ Dragutina Domjanića ne čitaju djelo Moja Zlatna dolina za lektiru.

Dragutin Domjanić nije na popisu pisaca čija djela, prema Nastavnom planu i programu za osnovnu školu, ulaze u popis lektire za osnovnu školu.

I Zlata Kolarić-Kišur i Dragutin Domjanić prisutni su u čitankama za osnovnu školu, ali odluka hoće li se njihovi tekstovi čitati ili ne pripada učiteljima.

Polazeći od načela zavičajnosti, kao jednog od temeljnih načela nastave Hrvatskoga jezika u osnovnoj školi, a ono pretpostavlja da se učeniku na poznatim sadržajima približe nepoznati i apstraktni sadržaji te da mu se dozvoli da svoje spoznaje iznosi na vlastitom, zavičajnom govoru kako bi te spoznaje primijenio i na druge književnojezične primjere (Težak, 1996.), Zlata Kolarić-Kišur i Dragutin Domjanić svojim su književnim i jezičnim izrazom, kako je već i rečeno, bliski dvama zavičajima: požeškom i kajkavskom. Odrednice se na prvi pogled čine neusklađene, ali proizlaze iz književnog opusa dvoje pisaca o kojima se u radu govori. Zlata Kolarić-Kišur na hrvatskom je standardu, koristeći se štokavskim narječjem u službi govorne karakterizacije svojih likova, požeškom čitatelju približila požeški kraj. Danas, s vremenskim odmakom, mladi se čitatelj teško može poistovjetiti s prikazom svakodnevnog života, ali se može poistovjetiti s nazivima mjesta koja i danas postoje i dio su života mladoga čitatelja: Jagodnjak, Vučjak, Tekija, Orljava, Stari grad, Sokolovac, Grabrik...

Žitelji kraja Dragutina Domjanića u kajkavskom izrazu, lirskim opisima, opjevanim običajima i motivima prepoznaju tradiciju prigorskoga kraja koja se njeguje i danas. U Domjanićevim pjesmama oživljavaju kipci iz svakodnevnog života. On pjeva o škrlačecu na vuhu, Božiću, teškim rožama, lozi koja raste po krovu od hiže, 
opjevava Kamenita vrata. Motivi u Domjanićevim pjesmama i današnjeg čitatelja Domjanićeva zavičaja pozivaju na prepoznavanje vlastite svakodnevice.

Učenici u 3. i 4. razredu, prema Nastavnom planu i programu za osnovnu školu na nastavi Prirode i društva uče o zavičaju. U 3. razredu upoznaju vrste zavičaja, a u 4. razredu uče o geografskim, prostornim, povijesnim i društvenim osobitostima svoga zavičaja. (NPP; 2006., 256-259) Radom se povezuje nastava Prirode i društva s nastavom Hrvatskoga jezika.

\section{Ciljevi istraživanja}

Postavljeno je nekoliko ciljeva koje se ovim istraživanjem željelo ostvariti:

1. Povezati nastavne sadržaje Prirode i društva i Hrvatskoga jezika (u prvom dijelu i samo na spoznajnoj razini).

2. Upoznati učenike s književnim radom Zlate Kolarić-Kišur i književnim radom Dragutina Domjanića.

3. Pobuditi zanimanje učenika prema pisanoj riječi i čitanju djela Zlate Kolarić-Kišur i Dragutina Domjanića.

4. Povezati načelo zavičajnosti, s načelom stvaralaštva te potaknuti učenike da i sami napišu tekst o zavičaju i na zavičajnom govoru. Željelo se ukazati na vrijednost zavičajnoga govora i njegovu slobodnu primjenu u književnom stvaralaštvu i u svakodnevnom govoru, pa i u školi. Jednako tako željelo se ukazati na činjenicu da je zavičajni govor važna značajka hrvatskoga jezika, da je dio hrvatskoga jezičnoga bogatstva te da je poželjno njegovati zavičajne govore.

\section{Uzorak}

U svibnju 2016. održana su četiri potpuno ista nastavna sata za učenike četiriju četvrtih razreda OŠ Dragutina Domjanića u Svetom Ivanu Zelini. U samom istraživanju sudjelovala su 93 učenika: iz 4 .a razreda 22 učenika, iz 4 .b razreda 24 učenika, iz 4.c razreda 22 učenika i iz 4 .d razreda 25 učenika.

\section{Rezultati}

a) Potičući učenike na prisjećanje nastavnoga sadržaja iz Prirode i društva o vrstama zavičaja i karakteristikama njihova zavičaja, učenici su sami zaključili da su njihovi zavičajni pisci oni što su rođeni i/ili žive u istom zavičaju iz kojega su i oni: Sveti Ivan Zelina i okolica. Dragutina Domjanića odmah su se sjetili i prepoznali kao zavičajnoga pisca jer škola koju pohađaju nosi njegovo ime.

Djela Zlate Kolarić-Kišur nisu čitali. Nitko. Nisu ni čuli za književnicu. Nisu čuli za zbirku pripovijedaka Moja Zlatna dolina. Poznat im je pojam Zlatna dolina te su 
samostalno objasnili na koji se hrvatski kraj pojam odnosi i koje su osobitosti Zlatne doline. Usporedili su ih s osobitostima svoga zavičaja i samostalno uočili sličnosti i razlike. Na geografskoj karti Republike Hrvatske istražili su područje Zlatne doline i područje Hrvatskoga prigorja.

Budući da je riječ o autobiografskoj zbirci pripovijedaka, učenici zaključuju da je Zlata Kolarić-Kišur zavičajni pisac svima koji žive na području požeškoga kraja. A budući da je dječji pisac, zaključuju da je knjiga s kojom će se susresti djelo namijenjeno djeci.

b) Kako bi se učenicima približilo djelo Zlate Kolarić-Kišur, kao književni predložak poslužila je priča Tko me vodio u prašume Konga iz zbirke Moja Zlatna dolina. Željelo se prikazati je li tko od zavičajnika imao utjecaja na književno stvaralaštvo Zlate Kolarić-Kišur. Priča je to o Dragutinu Lermanu, poznatom hrvatskom istraživaču (Afrike) i putopiscu, Požežaninu i obiteljskom prijatelju autoričine obitelji. Dok je uživala u zgodama koje je Dragutin Lerman pripovijedao na obiteljskim druženjima, autorica je upijala svaku njegovu riječ i u svojoj mašti putovala s njime u prašume Konga i plovila brodovima na njegovim istraživanjima. Sama, u svojoj pripovijetci, o tome kaže: „Ja sam se toliko uživjela u njegovo pričanje, da mi se činilo kako zajedno s njim dijelim sve dobro i zlo." (Kolarić-Kišur, 1986., 77) Autorica na duhovit način opisuje zgodu kada je na njezin 10. rođendan, u stanu Lermanovih, papiga, ptica iz Afrike, prestrašila nju i sluškinju Katu te je Kata pobjegla od straha i ostavila desetogodišnju Zlatu samu u mračnom stanu. "Jest, upamtila sam taj nevažan datum i skromnu proslavu možda baš zato, jer su povezani s čovjekom koji mi je poklonio ono najljepše što se može pokloniti djetetu: pregršt uzbudljivih i pustolovnih priča, kakve dječja mašta vječno priželjkuje." (Kolarić-Kišur, 1986., 82) Godinama kasnije nastaje priča o tome događaju te učenici zaključuju kako je pisac ostavio značajan trag u stvaralaštvu Zlate Kolarić-Kišur.

Na kraju ovoga dijela sata svih 93 učenika diže ruku da bi željelo pročitati cijelu zbirku pripovijedaka Zlate Kolarić-Kišur. Zaključuje se da se dobrom motivacijom može potaknuti učenike na čitanje.

c) Dragutin Domjanić inspiraciju za svoje pjesme nalazio je u svakodnevnim životnim trenutcima i zgodama. Crticom iz života Dragutina Domjanića učenicima se približava lik i djelo domaćega pisca. Postoji zapis da je tijekom šetnje turopoljskim krajem, u društvu turopoljskoga župana (komeša), iz jedne kuće izašla mlada djevojka. Pristojno ih je pozdravila, a na pitanje što radi, odgovorila je da je upravo tkala opremu za svoju udaju. Budući da je to izrekla neobično tužnim glasom, župan ju je upitao ne bi li trebala biti sretna ako se priprema za udaju. Djevojka im se 
požalila da se ona ne želi udati za onoga koga su joj roditelji odabrali, ali da je njezin odabranik siromašan i da ga njezin otac nikada ne bi prihvatio za zeta. Kako su u to vrijeme župani bili poprilično utjecajni i nije bilo neprilično da se miješaju u pitanja udaja i ženidbi, Dragutin Domjanić nagovorio je župana da razgovara s djevojčinim ocem. Otac nije ni znao da je njegova kći nesretna te da je zaljubljena u drugoga muškarca. Pristaje na to da se uda za onoga koga ona voli te su nakraju svi zajedno bili sretni. Na kraju toga dana Dragutin Domjanić napisao je pjesmu Tkeš si koja govori o opisanome događaju. Učenici su pjesmu Tkeš si čitali naglas, u razredu. Postojao je početni otpor prema čitanju pjesme na kajkavskome narječju. U svim je razredima pjesmu najprije pročitala učiteljica. Nakon nje i nekoliko se učenika odvažilo na čitanje pjesme.

Na pitanje je li im se svidjela i jesu li prepoznali opisani događaj svi su potvrdno odgovorili. Iz pjesme su izdvajali motive i povezivali ih s događajem koji je opisan u crtici iz života Dragutina Domjanića: tužna djevojka, tkanje, siromašni odabranik, bogati ženik.

d) Učenici su dobili zadatak da sami napišu pjesmu na zavičajnome govoru u kojoj će prikazati motive svoga kraja ili neku zgodu iz vlastitoga života. Pjesme su drugi dan predane razrednicama. Pristiglo je 87 radova učenika. 7 učenika napisalo je pjesme na standardnome jeziku, 80 radova pisano je kajkavskim narječjem. Tematski su svi radovi odgovarali zadanim okvirima.

\section{Zaključak}

Radom se željelo povezati Hrvatsko prigorje i Zlatnu dolinu. Željelo se povezati dva autora, naoko nepoveziva. Dva zavičajnika. Željelo se u Požegi, na znanstvenom simpoziju Dječji pisci Zlatne doline, govoriti o Dragutinu Domjaniću, a u Svetom Ivanu Zelini o Zlati Kolarić-Kišur.

Svi postavljeni ciljevi ostvareni su. Povezujući nastavne sadržaje Hrvatskoga jezika i Prirode i društva, učenici su pristupili analizi dvaju pisaca iz različitih dijelova Republike Hrvatske. Prepoznajući u njihovim zavičajnim odrednicama osobine pojedinih krajeva Republike Hrvatske, Slavonije i Hrvatskoga prigorja, pristupaju književnome tekstu. Poticajno je djelovala činjenica kako je bogata mašta djevojčice Zlate potaknuta i pričama njezina zavičajnika Dragutina Lermana. Dozvoljavajući piscu svoga zavičaja da ih ponese vlastitim primjerom, a slušajući crticu iz života Dragutina Domjanića, učenici su pisali na zavičajnome govoru, čitali tekstove na kajkavskome narječju u školi, u razredu, te su potaknuti da se jednako služe i hrvatskim jezičnim standardom i kajkavskim narječjem kao ravnopravnim sastavnicama hrvatskoga jezika. Djelo Zlate Kolarić-Kišur privuklo 
je čitateljsko zanimanje učenika i poželjeli su ga pročitati. Pjesme Dragutina Domjanića grade njihov kulturni integritet, daju osjećaj pripadnosti i potiču ih na stvaralačko izražavanje. Primjer je pjesma Nine Pivarić, djevojčice 4.a razreda, koja se nalazi u prilogu ovoga rada.

Učitelj je kreator. Uloga učitelja uvijek je motiviranje i vođenje učenika. Istraživanja su pokazala da „od svih školskih čimbenika kvaliteta poučavanja ima najvažniji utjecaj na kognitivne, emocionalne i bihevioralne ishode školovanja" (Bezinović, Marušić, Ristić Dedić, 2012., 12). Učitelji koji su svjesni ciljeva svoga predmeta vode učenike prema željenim obrazovnim postignućima i kompetencijama. U ovom radu potaknulo se učenike na čitanje zavičajnih i drugih književnih tekstova te na stvaranje na zavičajnom idiomu. Stvarajući poticajnu atmosferu, učitelj ima izuzetno važnu ulogu u prepoznavanju sposobnosti učenika i usmjeravanju učenika da svoje sposobnosti postupno razvijaju prema višim razinama znanja, u skladu sa svojim uzrastom, kako bi se one pretvorile u životne kompetencije.

Dobiveni literarni uradci učenika četvrtih razreda OŠ Dragutina Domjanića potvrđuju da je nastavni sat na kojemu su učenici upoznavali književno stvaralaštvo Zlate Kolarić-Kišur i Dragutina Domjanića, pri tome se poistovjećujući sa zavičajnim piscem, pokazao uspješnim i zanimljivim. Takvu nastavnu praksu treba nastaviti njegovati. Učitelj treba posezati za onim za što zna da je učenicima primjereno i zanimljivo, a nepoznato, i nuditi takve sadržaje kao dio nastave da bi učenike potaknuo da i sami proširuju svoje obzore i spoznaje kako bi samosvjesno razvili vlastite sposobnosti i kroz svoju raznolikost pridonijeli društvenom napretku.

\section{Literatura}

Knjige

Bezinović, Petar; Marušić, Iris; Ristić Dedić, Zrinka (2012), Opažanje i unapređivanje školske nastave. Zagreb: Agencija za odgoj i obrazovanje.

Domjanić, Dragutin (1994), Popevke. Zagreb: Mosta.

Domjanić, Dragutin (1994), V suncu i senci. Sveti Ivan Zelina: Matica Hrvatska, Ogranak Sveti Ivan Zelina.

Domjanić, Dragutin (2005), Petrica Kerempuh i spametni osel. Zagreb: Disput.

Hranjec, Stjepan (2009), Ogledi o dječjoj knjižeonosti. Zagreb: ALFA.

Kolarić-Kišur, Zlata (1986), Moja Zlatna dolina. Zagreb: Mladost.

Pavličević-Franić, Dunja (2005), Komunikacijom do gramatike. Zagreb: ALFA.

Težak, Stjepko (1996), Teorija i praksa nastave hrvatskoga jezika 1. Zagreb: Školska knjiga. 
Članci u časopisu

Skok, Joža (1983), Arkadijska obzorja kajkavskog pjesništva Dragutina Domjanića. U: Ivo Kalinski (ur.), Domjanićeva arkadija. Zagreb: Kajkavsko spravišče, str. 3-24.

Zbornik radova

Aladrović Slovaček, Katarina; Marić, Tamara (2013), Autobiografski i zavičajni elementi u stvaralaštvu Zlate Kolarić Kišur i Branka Hribara. U: Đurić, Tanja; Mahić, Ivana (ur.), Veliki dječji književnici/ce kao univerzalni kapital. Slavonski Brod: Učiteljski fakultet.

\section{Prilozi}

\section{Prilog 1}

Dragutin Domjanić: Tkeš si

Tkeš si fletno, tiho tkeš, čul sem: skoro zamuž peš.

Al se niš ne veseliš, kaj si tužna, ne veliš.

Na vrbine kiša pada, morti imaš drugog rada?

Pust se v polju trusi mak, kaj ćeš, gdo je siromak. Ni ti njega bilo žal, samo srce ti je dal. Još ti buju mutne oči, duge su kraj stranjskog noći. Tkeš si tiho, tugu tkeš, za bogatog zamuž peš.

(Iz zbirke V suncu i senci) 


\title{
Prilog 2
}

Nina Pivarić: KAJ

\author{
Kaj. \\ Čutim vu sebi \\ kaj. \\ Čutim pri tebi \\ kaj. \\ Predraga mi reč. \\ Živela bu \\ gda ne bu me več \\ gda ne bu me tu \\ živela bu.
}

(Učenica 4.a razreda OŠ Dragutina Domjanića,
svibanj, šk. god. 2015./2016.)

\section{Dragutin Domjanić and Zlata Kolarić-Kišur - Local Writers in Croatian Language Teaching in Primary Schools}

\begin{abstract}
Summary
Pupils come to school with the knowledge of their local idiom. In school, however, they meet the standard language and its rules for the first time. Nevertheless, apart from the tendency to teach pupils to master the standard language, Croatian language teaching should also strive to preserve the local idiom. The local principle is present in the methodology of Croatian language teaching, and it highlights the fact that the pupils should be educated through familiar contents and that various local vernaculars should be cherished, since they are the true treasure of Croatian language (Težak, 1997). Not only the standard language, but also Croatian dialects have their own place in Croatian language teaching; pupils should therefore be encouraged to the appropriate and correct usage thereof.

In the fourth grade of primary school, in science, pupils learn about the Republic of Croatia (National Curriculum, 2006). Connecting educational contents, this work will bring two regions - Croatian Prigorje (the area around Sveti Ivan Zelina) and Slavonia (the Požega area) - closer to pupils through the works by two writers: Zlata Kolarić-Kišur and Dragutin Domjanić. With her autobiographical stories and childhood reminiscences collected in the book Moja Zlatna dolina / My Golden Valley, Zlata Kolarić-Kišur has become a great local
\end{abstract}


template for learning about the Požega area in general (including relations among people, events and accidents during childhood) and about the rich Požega vernacular and local customs.

Selected poems by Dragutin Domjanić, in which pupils can recognise the characteristics of the foothill region of Zelina, customs that make this area special and represent a valuable cultural heritage, just as does the kajkavian dialect in which the poems are written, are the second literary template, through which pupils learn about the beauty of their region at Croatian language lessons.

This objective of this paper is to study to what extent literary templates are adequate as a form for learning about the closer and wider local region, and how ready pupils are to learn from the contents in their close environment: familiar local areas and language. Finally, another objective of the paper is to check whether pupils, motivated by the literature written in their local vernacular, feel ready to write any form of literary text about their region - either in their local idiom or in Croatian standard language.

Keywords: kajkavian dialect; štokavian dialect; local literature; local principle; Croatian language teaching.

Mr. sc. Gordana Čosić

OŠ Dragutina Domjanića

Ivana Gundulića 2, 10380 Sveti Ivan Zelina

gordana.cosic1@skole.hr 